\title{
Linguistic Layering: Social Language Development in the Context of Multimodal Design and Digital Technologies
}

Myrrh Domingo

Department of Teaching and Learning, New York University, New York, USA

(Received 16 December 2011; Final Draft 6 February 2012)

In our contemporary society, digital texts more readily circulate that extend beyond pagebound formats to include interactive representations such as online newsprint with hyperlinks to audio and video files. This is to say that multimodality combined with digital technologies extends grammars to include voice, visual, music, among other modes for articulating ideas beyond written language. In this paper, I discuss these multimodal designs in relation to a group of transcultural youth and their multilingual exchanges online. I examine patterns that reveal how their linguistic exchanges both drew from and extended beyond in-schools literacy practices. Using discourse and multimodal analyses, I examine data from a three-year ethnography that documents specific ways in which their multimodal design migrated across contexts and facilitated their social language development. In so doing, I describe their artistic approach to attending to language variety beyond code-switching through a process I identify as linguistic layering.

Keywords: literacy; language; text; composition; pedagogy; research; ethnography; multimodality; discourse; transcultural; youth; digital technologies; communication 


\section{Introduction}

With the rising use of digital technologies and the Internet, daily routines abound that more readily involve participatory and transcultural exchanges of cultural knowledge not previously possible with only page-bound texts. For example, reading current events via digital newsprint; inscribing ideas in blogs, wikis, or emails; and speaking with friends on sites like Facebook, Twitter and Skype. Images, sounds, among other features once considered ancillary to written language, now comprise layering capabilities for designing interactive texts that display the inextricable interrelationships among modes such as language, oral and written; images, still and moving; and sound, voice and music (Cope \& Kalantzis, 2000; Kress \& Van Leeuwen, 2001; New London Group, 1996). This evolved notion of literacy practice as textual design more readily takes into account that people's relation with language is a pliable artform (Bakhtin, 1981). Yet, page-bound and static texts still pervade most classrooms and are often divorced from the cultural contexts of students' lived realities (Freire \& Macedo, 1987). Flower (1994) argues that this compartmentalized learning, removed from social and cultural contexts, equates to "teaching a limited literacy" (p.12).

To this end, I examine the notion of layering or linguistic layering as significant to promoting socially and culturally relevant literacy practices. A working definition of linguistic layering identifies design and circulation of multimodal texts as rhetorical resources for managing linguistic variety and cultural affiliation across discourse communities. It takes into consideration the artistic remix involved in crafting multisensory texts that deftly layer modes both spatially and temporally to carry social and cultural meanings.

I explore shifts in reading and writing processes using examples of linguistic layering to illustrate how such practices are both informed by and extend beyond the reading and writing that transpires in schools. I consider some conceptual and pedagogical relationships among literacy, language, and layering as they are enacted multimodally and digitally. Lastly, I conclude with a discussion of linguistic layering within the context of classroom instruction and curriculum design.

\section{The Social Life of Texts}

The prolific use of videos, mobile devices, computers and other technological tools in everyday settings demonstrates how digital textual production is no longer exceptional but part of daily urban life in most countries (Banks, 2008; Hull, 2003; Kellner, 2001). The Pew Internet \& American Life Project (2009) identified that 93\% of teenagers use the Internet, and in so doing, they engage in such activities such as read about current events, shop online, share stories or videos, interact with peers via social networking or virtual gaming, and even search for online health topics or physical fitness information. Given this seemingly ubiquitous trend, reading and writing digitally among adolescents has been studied in terms of expanding what counts as texts and how such texts are circulated both locally and globally (Ball \& Freedman, 2004; Kirkland, 2008; Lam \& Rosario-Ramos, 2009; Lankshear \& Knobel, 2003). Other studies have explored how digital textual design opens spaces for expressing social identities and cultural knowledge (Alvermann, 2008; West, 2008; Williams, 2009). Further, current research suggests that youth engagement with digital texts and popular media is central to developing critical readers and writers (Buckingham, 2003; Doering, et.al., 2007; Lewis \& Fabos, 2005; 
Stone, 2007). Thus, there is shared recognition that while page-bound texts are necessary, they are inadequate for communicating in our changing world (Andrews, et. al., forthcoming; Domingo, 2011a; Kress, 2010).

I have previously identified how this shift in design from print to digital has profound impact on the ways that language can be shaped to convey meaning (Domingo, in press). Whereas print materials restrict language to fit page-bound dimensions, digital texts enable fluid migrations for multimodal meaning making. As Jewitt (2008) states, "multimodality attends to meaning as it is made through the situated configurations across image, gesture, gaze, body posture, sound, writing, music, speech" (246). This perspective deviates from past language and literacy traditions that championed the development of explicitly written text to autonomously represent meaning (Goody \& Watt, 1968; Olson, 1977; Ong, 1982). As such, literacy practices in our contemporary world are increasingly defined as including other forms of human communication besides written language in most social contexts (e.g., body language, oral language, visual representations).

Multimodality combined with digital technologies extends the meaning making potential whereby grammars can now include images, sounds, among other multisensory features once considered ancillary to written language (Mills, 2009; Pahl, 2007). The potential here is that there are layering capabilities for designing texts that display the inextricable interrelationships among modes such as language, oral and written; images, still and moving; and sound, voice and music (Kress \& Van Leeuwen, 2001; New London Group, 1996). This is to say that multimodal and digital textual designs can now more attentively carry fluid notions of culture as lived practices of sharing ideas across diverse linguistic communities (see Figure 1), whereby reading and writing practice does not yield a finite production of cultural artifacts but become part of an "interanimating relationship" with every new context (Bakhtin, 1981). For example, YouTube features both video and text comments to allow for interactive discussions about the posted material. Similarly, social networks like Twitter and Facebook permit users to retweet or repost comments and newsfeeds from other sources with an added personal message.

In the following section, I further explore multimodal texts as encompassing a social life and describe how this process takes into account that people's relationship with language in digital contexts is increasingly becoming a pliable artform. 
Figure 1: Examples of Social Texts

While this list is not exhaustive, it does display the ways in which the types of digital texts often used in urban settings take on social functions and embody cultural meanings through the use of multimodal and linguistic representation.

\begin{tabular}{|l|l|l|l|}
\hline $\begin{array}{l}\text { SOCIAL } \\
\text { FUNCTION }\end{array}$ & $\begin{array}{l}\text { DIGITAL } \\
\text { FORM }\end{array}$ & $\begin{array}{l}\text { LAYERED } \\
\text { MODES }\end{array}$ & $\begin{array}{l}\text { LINGUISTIC } \\
\text { REPRESENTATION }\end{array}$ \\
\hline $\begin{array}{l}\text { Community } \\
\text { Building }\end{array}$ & $\begin{array}{l}\text { Social Networks } \\
\text { (e.g., Facebook, } \\
\text { MySpace) }\end{array}$ & $\begin{array}{l}\text { sound, moving and } \\
\text { still image }\end{array}$ & $\begin{array}{l}\text { spoken, visual, } \\
\text { written }\end{array}$ \\
\hline $\begin{array}{l}\text { Cultural } \\
\text { Remixing }\end{array}$ & $\begin{array}{l}\text { Videos and Podcasts } \\
\text { (e.g., YouTube, iTunes) }\end{array}$ & $\begin{array}{l}\text { music and voice, } \\
\text { moving and still } \\
\text { image }\end{array}$ & spoken, visual \\
\hline $\begin{array}{l}\text { Conceptual } \\
\text { Sharing }\end{array}$ & $\begin{array}{l}\text { (e.g., WordPress, } \\
\text { Twitter) }\end{array}$ & still image, words & written, visual \\
\hline $\begin{array}{l}\text { Portfolio } \\
\text { Archiving }\end{array}$ & $\begin{array}{l}\text { Websites (e.g., Wix, } \\
\text { iWeb) }\end{array}$ & $\begin{array}{l}\text { sound, moving and } \\
\text { still image, words }\end{array}$ & $\begin{array}{l}\text { spoken, visual, } \\
\text { written }\end{array}$ \\
\hline $\begin{array}{l}\text { Interactive } \\
\text { Presenting }\end{array}$ & (e.g., Prezzi, Mindomo) & $\begin{array}{l}\text { still and moving } \\
\text { image, words }\end{array}$ & visual, written, \\
\hline
\end{tabular}

\section{Language as pliable artform}

Bakhtin (1981) conceptualization of language features a dynamic understanding of words and symbols, whereby utterances are not encapsulated in a vacuum but reside in living interaction with the social world (p.271). For example, he views language as embedded in a continually shifting system of social networks offers insight into the ways in which cultural artifacts that are always in transit through their endless process of remixing (Knobel \& Lankshear, 2008). In an ethnography of adolescent English language learners, Black (2009) identified how participation in online fan fiction sites afforded social narrative opportunities for language development, whereby construction of texts involved mixed media genres ranging from anime videos, lyrics of a song, movie elements, among other cultural materials. Similarly, Williams (2009) described how such participatory reading and writing opportunities across new media technologies allowed youth to express their social identities by reconstructing rhetorical texts that resemble "bricolage" and "collage" rather than traditional linear print (p.8).

Such perspective on literacy recognize the role of print and other symbol systems as integral to meaning making, and that such literate practices are mediated through social and cultural networks (Scribner \& Cole, 1981; Street, 1983). Kress (2010) articulates this human engagement with the social and semiotic world as culturally variable; as he writes, "What may be done by speech in one culture may be handled by gesture in another; what may be well done in image in one culture may be better done in 3D forms in another" (p.81). He describes the "reach" of modes as contextually specific, thus it cannot be assumed that modes carry the same translation across cultures (p.83). This is to say that language is rooted in a verbal-ideological system that indexes every 
generation at each social level, within varied cultural contexts as having its own language, vocabulary and accentual practices (Brutt- Griffler, 2002; Nero, 2006).

To extend this idea further, I assert that the blending of multimodality and digital technologies permits languages and literacies to also function as living, relational, and evolving cultural artifacts that can be artistically remade to welcome diverse linguistic and cultural voices. Such understanding is critical given that access to dominant discourse alone cannot bridge the divide between in-school and out-of-school literacy practices (Hull \& Schultz, 2001). The school and community channels must be opened at both ends for continuous flow of cultural patterns between social spaces. Without this reciprocal opening, student movement across contexts remains fixed on straddling boundaries rather than bridging the divide between their in-school and out-of-school literacy practices. How might new conceptualizations of schooling be informed by the global voice and digital dexterity that youth possess in the twenty-first century?

\section{From code-switching to linguistic layering}

We know from current research that it is inadequate and risky to define literacy as a finite set of competencies in a global and digital world (Brutt-Griffler, 2007; Gee, 2004; Hull, et.al, 2009; Lam, 2006). Yet, there is cause for concern that while policies and practices are enacted in an attempt to improve student performance on a national scale, most schools today remain fixed on teaching reading and writing as mastering a limited skillsset often void of socially and culturally responsive pedagogy (Conley, 2008; Flower, 1994; Freire \& Macedo, 1987; Kellner, 2001; Moll, 2009). The educational inequity that results from this pervasive ideological structure often manifests in the daily teaching and learning routines of schools, whereby diverse ways of speaking and acting are governed to comply with a homogenizing literacy curriculum (deCerteau, 1984; Gee, 1996).

I argue that among the ways that this linguistic splintering transpires is when the sociocultural dimensions of language are deemed secondary to its cognitive and linguistic functions (Alvarez-Cáccamo, 1998; Auer, 1998). Different social spaces require distinctive ways of communicating and behaving (Bourdieu, 1977; Foucault, 1980). It is exhausting - physically, mentally, emotionally - to alter aspects of one's being in-school and out-of-school to transact with people, thoughts and texts (Adger, et. al, 2007; Dowdy, 2002; Kachru, 2006). For example, Kirkland (2004) argues that those who control the teaching of writing also influence the social dimensions of student learning; hence, those who standardize literacy instruction inevitably also restrain the ways in which students think, believe and behave. This linguistic alteration has often been studied in terms of code-switching as a sociolinguistic and cognitive process (Cenoz \& Genesee, 2001; DiScullio \& Williams, 1987; Goffman, 1979; Sankoff \& Poplack, 1981). Emphasizing such fragmented models of schooling can have a detrimental effect on the social language and literacy development of students, particularly for those who function outside the mainstream cultural perspective (Canagarajah, 1999; Leung, et.al., 1997; Widdowson, 1994). At a broad level, socially and culturally responsive teaching must recognize these tensions that youth experience in trying to bridge the discourse divides that often prevail in daily life. While code-switching has been studied to account for these diverse social and conversational interaction (Bailey, 2001; Heller, 1999; Myers-Scotton \& Bolonyai, 2001), it does not fully address how diverse students might capitalize on the dialogic and hybrid nature of their languages and literacies (Brutt-Griffler, 2007; Jayakumar, 2008; 
Lam, 2006; Suarez-Orozco \& Qin-Hilliard, 2004). It is for these aforementioned concerns that I explore notions of linguistic layering, multimodal practices, and digital textual production.

In this article, the social language development of the youth studied will be examined to reveal the migratory nature of their literacy practices. Contrasting a fossilized view of language, the notion of linguistic layering will be explored as a means for describing how the youth cultivated hybrid language identities. Given their distinctive ways of reading and writing using digital technologies, this article offers insight into new ways that the youth design multimodal texts to extend grammars beyond speech and writing to also include other modes. Further, I address how layering enabled the youth to build upon their range of linguistic and cultural repertoire rather than shifting their practices to only adopt the languages and literacies of a particular context.

\section{The Study}

Data discussed for this paper comes from a three-year ethnography of six Filipino British youth in London, who call themselves Pinoys. The research was directed at examining their multilingual and cross-cultural practices across diverse discourse spaces, both physically and digitally mediated. The study drew from and contributed to research in New Literacy Studies (Gee, 1996; Street, 1993) and aimed to examine enactments of linguistic and cultural identities as multimodally situated across transcultural contexts (Lam \& Rosario-Ramos, 2009; Levitt \& Jaworsky, 2007; McGinnis, et. al, 2007; Yi, 2009). As such, the following questions guided the larger research study: How do language and literacy crossings of the Pinoys shape their social identities and cultural practices? How do the Pinoys assert their social identities as they migrate across physical and online spaces? How might understanding the Pinoys social identities contribute to new conceptualizations of language and literacy? Contrary to the stillness that comes with viewing literacy as a fixed skill set, the findings of this ethnography illustrated the ways in which the Pinoys engaged reading and writing that migrated across contexts. The study displayed how agency and dialogic participation were predominant features of their multimodal textual production, whereby active remix and reconstruction of multisensory texts embodied diverse discourses (Domingo, 2011b). For this paper, I will focus on elaborating the process for linguistic layering as made empirically evident in the Pinoys' literacy practices.

\section{Participants}

My purpose in studying the Pinoys was to understand how they layered their linguistic diversity and cultural knowledge to navigate their social worlds. Given the scope of the research, it was necessary to work with participants who were ardent readers and writers, avid users of digital technologies and prolific producers of multimodal texts. Further, it was necessary to work with youth who interacted with both local and global audiences. The six participants featured in this study fit this description. During a study abroad course in London, I visited various community centers. At one of these sites, I met a key informant who introduced me to the Pinoys. All six participants lived in London during the course of this research. Throughout the course of data collection, they closely associated with one another as members of an urban youth hip hop production that included a total of 50 Filipino youth members worldwide. This diverse representation 
allowed for documentation of the multiple ways that these youth, who have different backgrounds but share the same peer group, navigated cultural identities and social belonging through linguistic layering.

\section{Procedures}

Because the Pinoys were constantly moving across diverse digital and physical spaces (e.g., interacting with multilingual peers on Facebook or meeting them in person perform music), it was problematic to study their everyday practices of literacies as rooted only in the placed-based structures that they frequented. The scope of my research necessitated that I also display the ways in which the Pinoys were actively layering their language as an artform across discourses. I have previously identified this research approach as "migratory" whereby ethnographic inquiry spans both the work navigable by the body and as mediated online (Domingo, 2011c). I drew from ethnographies of media to enhance my understanding of the Pinoys' linguistic diversity, cultural knowledge and social identities from rooted-space orientations to more fluid arrangements ${ }^{1}$ (Condry, 2006; Dornfeld, 1998). This migratory approach provided new possibilities for studying additional everyday learning spaces in the lives of the Pinoys (e.g., composing music on a mobile phone while riding public transportation or creating a radio podcast for circulation on a global scale). To this end, data for this research is collected through both online and offline interactions and integrates three ethnographic methods: (1) conducting semistructured interviews and focus group interviews; (2) recording descriptive and reflective field notes from participant observations; and (3) collecting literacy artifacts (Bogdan \& Biklen, 2007; Dyson \& Genishi, 2005; Heath \& Street, 2008).

In addition, the literacy artifacts I collected were often "noisy and moving," and could not be captured using traditional transcription methods (e.g., audio data that is transcribed line by line). ${ }^{2}$ As such, I had to develop both a spatial and temporal reading path that could visually display these layering functions (Domingo, 2011d). This multimodal analytic approach also visually depicts the social and cultural significance of multimodal textual designs. For example, the use of color as a visual mode often included the colors of the Philippine and British flags for the Pinoys. Similarly, the rhythmic beat of songs often resonate a hybrid remix of their belonging across Filipino, British and hip hop communities.

\section{Linguistic Layering as Cross-cultural Remix}

\footnotetext{
${ }^{1}$ In so doing, meaning making of the data moved beyond Third Space (Bhabha, 2004) literacy conceptualizations, whereby in-school practices and out-of-school practices overlap to create an intermediary space. Further, just as my work moves away from a causal relationship between orality and writing, ethnography of media moves away from causal effects of technology on the lives of people. Instead, there is an emphasis on the social practice of media, which attends to understanding how people manipulate technologies to attend to their own culture, economy, and ideology.

2 I would like to differentiate my literal use of the term "noisy and moving" to describe the Pinoys' textual products from studies in dyslexia that also reference words as having animated qualities despite being page-bound. As such, this research is not referencing dyslexic symptoms that impair visual perception of written text. Throughout this dissertation, I apply the term to conceptually allude to the Pinoys' language and literacy practices as socially and culturally mediated (Scribner \& Cole, 1981; Street, 1983; Vygotsky, 1978).
} 
In this section, I discuss the linguistic layering ${ }^{3}$ that the Pinoys employed as a literacy practice. I account for the ways in which they navigated movement across the discourse communities of Filipino, British, hip hop and youth pop culture in the analyzed data sets for their textual production of the music "Pinoy Ako" [I am Filipino]. I also demonstrate how their multimodal textual practices and digital design facilitated social language development.

I assert that linguistic layering for the Pinoys functioned as a form of crosscultural remix. For example, "Pinoy Ako" [I am Filipino] is a rap song lyrically composed by Aziatik in Tagalog, the native language of the Philippines, to teach Filipino youth about their heritage. The hybrid multimodal text was designed with the assistance of one of the beat-makers in the group. While previous research (Courtland \& Paddington, 2008; Wheeler, Yeomans, \& Wheeler, 2009) has noted the collaboration among online members as fostering literacies, the Pinoys extended this practice beyond writing to also include social and cultural interactivity. For example, the accompanying hip hop beat for "Pinoy Ako" was a remix of a beloved traditional Filipino folk song called "Tinikling." The process involved manipulating a one-second clip from the introduction of the folk song through the music software Cubase and layering it with instruments such as harp, piano, strings, among others, using digital beat-making tools. Aziatik and Lucky QBall articulated this linguistic layering as a form of cultural remix that not only means making music but as creating a "culture song." As Aziatik stated, "Kids nowadays they don't know this kinda stuff, obviously they don't learn it in school...so we want something for them to yung maalala nila yung culture nila" [remember their culture]. Rampton (1995) describes these cultural interpretations of one's relationship to language as reflective of linguistic identities, ${ }^{4}$ whereby speakers consciously signal their language loyalty through acts of affiliation and inheritance. As he articulates,

...affiliation refers to a connection between people and groups that are considered to be separate or different, whereas inheritance is concerned with the continuity between people and groups who are felt to be closely linked. Inheritance occurs within social boundaries while affiliation takes place across them. (p. 342) The multimodal design of "Pinoy Ako" demonstrates how Aziatik deftly signaled his affiliation towards the discourse communities of Filipino, British, hip hop and youth pop

\footnotetext{
${ }^{3}$ It is significant to note that this article proposes layering to move beyond traditional structures of grammar in literacy classrooms to attend to its migratory features in digital and multimodal settings. For example, Kress (2010) aptly described how the grammar of multimodal meaning making has often been described using the standard conventions for reading and writing; however, such conventions do not fully capture the language of grammar in multimodal texts (p. 240). Still, I find it useful to make connections between the grammars of the Pinoys' multimodal design and the grammars of the literacy classrooms as such bridging provides insight into how the Pinoys are blending the often competing discourses of in-school and out-of-school settings. Further, by focusing on how multimodality extends traditional grammatical structures, this article contributes new ways for conceiving of parts of speech as having hybrid and interactive design. In so doing, it presents a view of literacy as an active process that engages students to artistically shape and layer modes as a cultural and linguistic resource.
}

${ }^{4} \mathrm{He}$ argues that referencing speakers as merely being 'native' or 'non-native' fails to recognize the dynamic social processes involved in negotiating their language loyalty in multilingual settings. 
culture. It is also a text that is concerned with inheritance, as Aziatik's constructive aim was to share cultural knowledge among Filipino youth. Further, the physical and conceptual layering involved in Aziatik's hybrid lyrical and beat-making for "Pinoy Ako" illustrates how he artistically crafted social language into his own voice (Bakhtin, 1981). It is through this artistic reworking - the tension-filled practice of listening to the social cadence of language and interjecting one's own sound to its historical orchestration-where I locate Aziatik's linguistic layering.

Describing himself as a "conscious lyricist," Aziatik took pride in artistically designing hip hop music that extends beyond entertainment to also include educative purposes. In this particular song, his multimodal design encompassed linguistic layering of sounds and words, hip hop and folk music, traditional Filipino and British youth pop culture, to articulate a hybrid cultural rendition of "Tinikling" that more flexibly attends to the transcultural experience of multilingual youth. As made visible in the second verse of his lyrics (lines 17-20), he called forth the participation of a new mixed sense of Filipino British youth.

17 Pang bansang tunog nadinig mo ng una.

[The sound of my country will be heard first.]

18 Aking y hahandog sa makabagong kultura.

[I am offering it to my new culture]

19 upang di malimutan ang ating tradisyon

[so I do not forget my tradition]

20

at ipapakilala sa bagong generation.

[and I show it to the new generation.]

Although Aziatik has lived in London for over ten years and completed most of his secondary schooling in British schools, he still fluently speaks and writes in Tagalog. As made visible in the partial verse display of "Pinoy Ako" (lines 17-20), Aziatik's active participation in multimodal design and hip hop production has provided him with a platform to express his ideas while also preserving his cultural and linguistic identity.

\section{Multimodal design as instructional and grammatical layering}

As evidenced by the previous example, participating in multimodal design was among the ways that the Pinoys cultivated linguistic layering to embed social and cultural meaning in their texts. In this section, I explore this multimodal design and identify two types of linguistic layering that transpired: instructional layering and compositional layering. Rather than merely adopting actions to suit the norms of one context or another, the Pinoys practiced an integration of discourses through the remixing sounds and gestures. To demonstrate this hybrid construction, I examine how Aziatik's multimodal design of "Pinoy Ako" enabled social language development via the use of instructional and grammatical layering.

Instructional layering of modes permitted new ways for expressing ideas beyond written or spoken language to also include an interactive performance. For example, multimodal transcription of Aziatik's discussing and rapping of "Pinoy Ako," shows how he moves from merely describing the history and culture behind the artistic remake of the song to actually performing it. In this way, it is discernable how his multimodal design functions as interactive instructional practice about language and cultural remixing. To identify his avid movement across discourse communities by linguistic layering of 
modes, the modes were color-coded (see Figure 2). At the time of this observation, Aziatik has not completed recording the entire song; therefore, he has yet to memorize all of the lyrics. As such, his performance involved reading the lyrics on the screen as he rapped to the remixed beat playing on the computer.

Figure 2: Multimodal Analysis and Transcription Codes for "Pinoy Ako" These codes display the four predominant modes Aziatik used to create a hybrid text

\begin{tabular}{|l|l|l|}
\hline Mode & Enactment & Textual Representation \\
\hline Images & Digital text & Online text, YouTube videos, mp3 files \\
\hline Movements & Gesture and gaze & $\begin{array}{l}\text { Hand gestures, head movement, gaze of } \\
\text { eyes }\end{array}$ \\
\hline Words & Speech and song & British English, Tagalog \\
\hline Sounds & Music & $\begin{array}{l}\text { Filipino, hip hop patterns, hip hop } \\
\text { metaphors }\end{array}$ \\
\hline
\end{tabular}

In transcribing the multimodal data, four predominant modes emerged: images, movements, words and sounds. Aziatik weaved these four modes through a layering pattern. Linguistically, Aziatik extended beyond traditional grammars to form dialogic texts that were noisy and moving. A partial color-coded transcription of Aziatik's "Pinoy Ako" performance visually depicts his instructional layering in action.

Aziatik: $\quad$ ((plays music)) ((lowers volume)) ((opens text of lyrics)): Ito lyrics nya, te [Here are the lyrics, sis].

Me: $\quad$ Mmmm.

Aziatik: $\quad$ ((Reads lyrics)) ((Raps to the beat))

((moves hand to the beat)):

Intro: $\quad$ Pinoy Ako, y sigaw mo. Pinoy Ako,

4 lines: $\quad$ Pinoy Ako, y sigaw mo. Pinoy Ako.

Go, ((hand gesture)) y sigaw mo. Pinoy Ako.

Pinoy Ako, Pinoy Ako, Pinoy Ako.

Multimodal analysis made visible Aziatik's linguistic layering not as embedded in a fixed textual product but as a moving and noisy text form. ${ }^{5}$ For example, he began the performance by invoking hybrid sounds and voices that announced his social and cultural affiliations. He plays the hybridized "Tinikling" beat, adjusting the computer volume and calling forth the lyrics on screen. Before he begins, he says to me, "Ito lyrics nya, te"

${ }^{5}$ Aziatik used elements of hip hop in "Pinoy Ako." He said he used an "old school" beat measure rather than the faster-paced British grime popular among his peers during the time this piece was developed. Further, Aziatik applied an internal and external rhyme pattern. His gestures tied metaphors together by pairing words to create double meanings. 
[Here are the lyrics, sis]. ${ }^{6}$ As his primary audience, he awaited my acknowledgement before he started rapping. In this regard, Aziatik was signaling the design of a dialogic text that beckoned a call and response mechanism, whereby audiences are also performers and not merely passive listerners (Alim, 2006). This action also connotes Aziatik's invitation to embrace the Philippine culture. As he was aware of my fluency in speaking but lack of proficiency in writing Tagalog, this was among the many invitations he extended for me to embrace the language and not merely observe its use as a researcher. He was enacting what Rampton (1995) described as language loyalty, while also encouraging my language development. Rather than adopting a traditional-teacher stance by instructing me to read the lyrics, Aziatik invited rather than lectured how I should interact with the group, their processes and their texts. He allowed me to enter his discourse communities as an agentive participant.

Grammatical layering of modes is yet another form of linguistic layering that the Pinoys employed as literacy practice. For example, as Aziatik began to rap the song "Pinoy Ako" in Tagalog, his grammars extended beyond spoken language to also include gesture, which he stylistically layered to accentuate his meaning. Multimodal analysis revealed that Aziatik used gestures not as additive ways of making meaning but as an integral component of sharing his ideas. This is to say that his speech, gestures, use of digital technologies and music, all contributed to deliver a coherently layered meaning in this performed text. Further, Aziatik's layering of modes in this hybrid composition could be categorized in his use of gesture and gaze for the following linguistic purposes: exploratory, descriptive and metaphorical writing (see Figure 3). ${ }^{7}$ Specifically, Aziatik configured his gestures to layer his use of tonal semantics and poetics, which consist of "talk-singing, repetition and alliterative word play, intonational contouring and rhyme..." (Alim, 2006, p. 84-86). Thus, Aziatik's "Pinoy Ako" is a lyrical composition of words, gestures, images and music. In this way, his sentences are not merely written texts but also multi-sensory.

${ }^{6}$ The Pinoys did not always use my first name. They sometimes referred to me as "ate" [sister] or "te" [sis]. In the Philippine culture, elders-whether family or friends or even acquaintances- are often called sister or brother as a sign of respect. 
Figure 3: Gesture and Gaze as Grammatical Layering

Aziatik's use of linguistic layering promoted the use of grammars beyond words to also include modes such as gesture and gaze for instructional purposes

\begin{tabular}{|c|c|c|c|}
\hline Gesture/Gaze & Transcription & $\begin{array}{l}\text { Linguistic } \\
\text { purpose in } \\
\text { writing }\end{array}$ & $\begin{array}{l}\text { Layered } \\
\text { meaning } \\
\text { making }\end{array}$ \\
\hline $\begin{array}{l}\text { points to } \\
\text { computer }\end{array}$ & $\begin{array}{l}\text { Yea..yea..((points } \\
\text { to computer)) And } \\
\text { and we cut it. }\end{array}$ & $\begin{array}{l}\text { explanatory } \\
\text { language }\end{array}$ & $\begin{array}{l}\text { Aziatik was } \\
\text { directing my } \\
\text { participation } \\
\text { process to link } \\
\text { his auditory } \\
\text { instructions } \\
\text { with visual } \\
\text { display }\end{array}$ \\
\hline $\begin{array}{l}\text { scratching a } \\
\text { record with his } \\
\text { hand }\end{array}$ & $\begin{array}{l}\text { so we took a } \\
\text { scratch beat } \\
\text { ((scratching a } \\
\text { record with his } \\
\text { hands)), like the } \\
\text { deejay use }\end{array}$ & $\begin{array}{l}\text { descriptive } \\
\text { language }\end{array}$ & $\begin{array}{l}\text { Aziatik was } \\
\text { instructing the } \\
\text { remixing } \\
\text { process of the } \\
\text { "Tinikling" beat } \\
\text { into "Pinoy Ako" } \\
\text { by using hand } \\
\text { gestures }\end{array}$ \\
\hline points to mouth & $\begin{array}{l}\text { Gamit ko ang } \\
\text { wika((points to } \\
\text { mouth)) ang } \\
\text { pinapalang((points } \\
\text { to mouth)) dila [I } \\
\text { use my birth } \\
\text { language like a } \\
\text { candle] }\end{array}$ & $\begin{array}{l}\text { metaphoric } \\
\text { language }\end{array}$ & $\begin{array}{l}\text { Aziatik was } \\
\text { coaching my } \\
\text { understanding } \\
\text { of the double } \\
\text { meaning of the } \\
\text { word "wika" } \\
\text { [wick/dialect] }\end{array}$ \\
\hline
\end{tabular}

In this section, I further describe Aziatik's use of metaphoric language to display how linguistic layering promoted the circulation of language diversity and cultural knowledge. For example, Aziatik's multimodal design of "Pinoy Ako," included a multilayered internal and external rhyme scheme that included linguistic and gestural couplings (Kress \& Van Leeuwen, 2001). I demonstrate using bold font (lines 13-16) how the word before the gesture and the last word of each line are linked linguistic metaphors tied together by Aziatik's gestures. ${ }^{8}$ The most vivid display of this coupling is evident when he described his birth language as reminiscent of a burning candle (lines 14-15). The word "wika" has a double meaning in Tagalog. In a more basic sense, it can be translated to mean the wick of a candle or to mean language and dialect; hence, when he said that he uses his birth language like a candle, there is both a literal and figurative migration required of the listener to comprehend the meaning. Because "wika" [wick] is most often associated with "candila [candle], it is not as commonly used by Filipino youth to refer to language or dialect. Given this distinction, Aziatik purposely points to his mouth when he says "wika" and gestured after "candila" with his right hand, what appeared to be the light of a candle rising up.

\footnotetext{
${ }^{8}$ While the English translation fails to vividly display the connection in a way that his Tagalog lyrics makes visible, it is still useful to view the translation as contextual background.
} 
13 Wala man sa pinas ((raises right hand up)) tinataas ang bandila.

[He carries the flag of his birth country even if not there.]

14 Gamit ko ang wika ((points to mouth)) ang pinapalang dila

[I use my birth language]

15 parang candila ((gestures with right hand)) ako ay nagaapoy.

[like a candle I burn bright.]

16 Patulo sasabihin mabuhay ang Pinoy ((raises right hand up)). [As I burn I cry long live the Filipinos.]

Aziatik's artistic lyricism in "Pinoy Ako" not only spoke to the discourse of hip hop but also to that of Filipino and British linguistic grammars; it not only spoke of Aziatik's connective allegiance to Philippines but also of how this allegiance can spread like a brightly burning flame. By coupling speech and gesture, Aziatik moved beyond traditional conventions of composing to shape a multimodal text. His linguistic layering offered opportunities for social language development as the gestures not only pointed to a metaphorical connection among words but also functioned as cues connecting visual meaning to what might be unfamiliar Tagalog words for listeners.

These examples also demonstrate how transcultural exchanges of multimodal designs among the Pinoys facilitated linguistic layering, and served to extend their social language development.

\section{Linguistic Layering and Schooling}

In this last section, I draw from the research to provide pedagogical implications. I address ways for understanding how the Pinoys' multimodal design practices are in fact both informed by and extend beyond the reading and writing that transpires in schools. Making this connection is particularly relevant given that access to dominant discourse alone cannot bridge the divide between in-school and out-of-school literacy practices (Hull \& Schultz, 2001). I argue that the school and community channels must be opened at both ends for continuous flow of cultural patterns between social spaces. Without this reciprocal opening, student movement across contexts remains fixed on straddling linguistic boundaries. How might research conceptualizations about multimodality and social language development be informed by the global voice and digital dexterity that youth possess?

\section{Instructional layering in classrooms}

As empirical evidence revealed, artistically writing lyrics, recording music and crafting videos extended the Pinoys' linguistic identities and social language development. This finding supports positive research implications linking digital and multimodal learning as providing youth with new ways of complexly articulating meanings (Hull \& Nelson, 2005; Lewis \& Fabos, 2005). However, such literacy practices are often divorced from literacy instruction; thus, a reductive attitude towards literacy still dominate most classrooms. To this end, literacy resources like textbooks inadvertently become "tools of disempowerment" rather than teaching students to "read the word and the world" (Flower, 1994; Freire \& Macedo, 1987). Such a deficit model of engaging with literacy texts contradict current research that identify youth interaction with digital and 
multimodal material as central to developing critical thinking in the context of globalization (Alvermann, 2008; New London Group, 1996; Williams, 2009).

In considering the relevance of this study to pedagogical content, I suggest adapting the findings to re-imagine instruction in schooling to include multimodality as part of lesson planning and instructional design. By this I mean to say that teachers can view not only digital technologies or page-bound texts as their material resources for carrying out instruction but also their own minds and even their bodies as integral to multimodal pedagogy. Until I embarked upon this research, I was narrowly defining what counts as text in the literacy classroom to only include formalized and published documents (e.g., textbooks, workbooks, novels). In speaking with the Pinoys and documenting their ways with words, it became vividly apparent that social interactivity and the sharing of cultural knowledge are predominant features of their literacy practices. Similarly, classrooms that reduce text usage and instructional design to page-bound resources negate the importance of multimodal and multisensory expression for conveying ideas to diverse learners. A teacher who actively engages in the linguistic layering of modes like gestures, images, words, will promote a more diversified approach to learning that welcome varied learning styles.

I posit that a meaningful multimodal pedagogy begins with a reflexive attitude rather than a digitally savvy lesson plan. Start by documenting the multiple multimodal and digital resources that are already part of one's teaching repertoire (e.g., documentaries, smartboards). In this inventory process, it is possible to start including within one's lesson plans a list of multimodal resources that are already in use for a particular unit or even specific lessons. In this way, teachers become more aware of the varieties of multimodal texts that they employ on a regular basis.

Also, included within this critical practice is the concept of a teacher's body as a form of multimodal text. Positioning in the classroom, voice intonations, and even gestures become a form of linguistic layering that teachers can deftly use to carry out multimodal instruction. This physical awareness can serve to expand instructional delivery beyond a familiar or repetitive nature to include layering of language and literacy practices that better attend to the various learning styles of students.

\section{Grammatical layering in the curriculum}

Research cites positive engagement of students when the means by which instruction is delivered connects to their own lives (Beck, 2009; Moje, et, al., 2008; Rubenstein-Avila, 2007; Wolsey \& Grisham, 2007). As such, it is equally critical to consider the ethical implications of literacy pedagogies on students' lives and not privilege academic performance as the prime measurement for student success (Christenbury, 2008; Greene, 1995, 2001). Rather than viewing language and socialization as divergent domains, this study offered a more integrated perspective of what it means to actively engage in the life of speech across social and cultural contexts through the notion of linguistic layering.

To this end, I suggest adapting the findings about the Pinoys' grammatical layering to classroom pedagogy. First, I find it useful to think about grammar lessons as an opportunity to engage in multimodal teaching practices. By this I mean allowing learning to transpire beyond page-bound texts (e.g., grammar workbook units or worksheets about parts of speech) to also include multisensory representations. For example, blending written, spoken and even performed texts to shape students' understanding of language 
that is alive in social interaction. Literacy lessons could be designed to include video texts whereby words are layered with other modes to express meanings that are embedded in contextual conversations. In this way, grammatical lessons are not reduced to memorization of discrete semantic features of language but incorporate a social and cultural component. For example, students can learn the parts of speech and create video commercials, documentaries, and even music videos that will involve creating scripts, then enacting this written text to include other modes such as sound, voice, music, gestures. In this process, layering of modes becomes a way to access grammar concepts such as the part of speech in more interactive ways, both cognitively in terms of how to understand the definitions but also instructionally whereby students are not passive interpreters of text but also digital designers of multimodal meaning. Further, this visual display is not reduced to a final product of a video-text but can also integrate other writing processes that will expand students' grammatical layering of modes to include audience awareness. One such example would be developing the DVD cover for the filmed video that will include a synopsis, still images that symbolically capture the essence of the short film, and a title that signifies the core ideas of the video. All of these literacy activities provide a multimodal experience to expand notions of grammar lessons that engage students in artistically crafting language as a pliable artform (Bakhtin, 1981). The effort involved in individually and collaboratively completing the aforementioned literacy activities requires students to think of words, grammar and their social function not as discrete concepts but as interconnected features of language for conveying meaning to a larger audience.

I offer the use of video-texts as a means to engage students in multimodal design. This layering practice in digital contexts bridges research findings about the Pinoys' social language development in ways that will be beneficial for schooling purposes. In studying the ways that they engaged linguistic layering, it was possible to see how their syntactical structure both adhered and pushed against standardized English grammars. By designing moving and noisy texts, they extended grammars to also include new textual features (Mills, 2009; Pahl, 2007) that made possible traversals across diverse discourse communities. Similarly, students who design video-texts will have opportunities for crafting cultural artifacts that feature grammatical layering as a cornerstone of meaning making.

\section{Conclusion}

While this research focused on Filipino British youth, the findings are relevant for educators who are searching for new ways to imagine academic experiences that are socially and culturally responsive. As such, the complexity of the Pinoys' critical literacy practices bear particular relevance for students often defined as "struggling" in academic settings and for the teachers who work with these "at-risk" students. The Pinoys are among the students who would be labeled within these categories given their socioeconomic and educational backgrounds. However, as this study illustrated, the Pinoys' non-compliance with standardized literacy curriculum does not equate to indifference for learning. Instead, empirical evidence made visible how interactive literacy learning transpires for the Pinoys through transcultural exchanges in multimodal and digital environments. For example, the Pinoys' multimodal design enabled their 
social language development by culturally remixing their ideas and texts through linguistic layering, and thus producing hybrid texts like "Pinoy Ako."

The pedagogical implications offered in this research extend notions of literacy to also include instructional and grammatical layering in ways that promote social language development. The offered approaches are by no means exhaustive but begin to map how teachers and students alike can benefit from multimodal pedagogy and linguistic layering given that both foster social and cultural awareness of language, literacy and learning.

\section{Acknowledgements}

The author would like acknowledge the National Academy of Education and the Carnegie Foundation for their support in completing the ethnographic research of the Filipino British youth in London.

\section{Notes on the Contributor}

Myrrh Domingo is currently a Visiting Assistant Professor in English Education and Literacy Education at New York University. She studies language and literacy development in the context of digital technologies and globalization. Her research explores the migration of people, their cultural texts, and their linguistic identities across physical and digital communities. Her recent publication appears in The International Journal of Social Research Methodology and features her focus on ethnographic and multimodal research methods to understand new ways in which transcultural reading and writing transpires in digital and online communities. She is also currently working with international scholars on The Sage Handbook of Digital Dissertations and Theses, a project funded by the United Kingdom's Economic Social Research Council that examines the influence of multimodality and e-learning on the shifting nature and design of doctoral theses.

\section{References}

Adger, C.T., Wolfram, W. and Christian, D. (2007). Dialects in Schools and Communities. Mahwah, New Jersey: Lawrence Erlbaum Associates.

Alvarez-Cáccamo, C. (1998). From 'Switching Code' to 'Code-switching': Towards a Reconceptualization of Communicative Codes. In P. Auer (Ed.), Code- Switching in Conversation: Language, Interaction, and Identity (pp.29-48). London: Routledge.

Alvermann, D.E. (2008). Why Bother Theorizing Adolescents' Online Literacies for Classroom Practice and Research? Journal of Adult and Adolescent Literacy, 52(1), 8-19.

Andrews, R., Borg, E., Boyd, D., Domingo, M., \& England, J. (Eds.). (in press). Handbook of Digital Dissertations and Theses. London and Thousand Oaks, CA: Sage. 
Appadurai, A. (1996). Modernity at Large. Cultural Dimensions of Globalization. Minneapolis: University of Minnesota Press.

Auer, P. (Ed.). (1999). Code switching in conversation. New York: Routledge.

Bailey, B. (2001). The Language of Multiple Identities among Dominican Americans. Journal of Linguistic Anthropology, 10(2), 190-22.

Bakhtin, M.M. (1981). The Dialogic Imagination: Four Essays. Bakhtinian Perspectives on Language, Literacy and Learning. Cambridge: Cambridge University Press.

Ball, A.F. \& Freedman, S.W. (2004). Bakhtinian Perspectives on Language, Literacy and Learning. Cambridge: Cambridge University Press.

Bauman, Z. (1998). Globalization: The Human Consequences. New York: Columbia University Press.

Beck, S. (2009). Individual Goals and Academic Literacy: Integrating Authenticity and Explicitness. English Education, 41(3), 259-280.

Bhabha, H. (2004). The Location of Culture. New York: Routledge.

Black, R. (2009). Online fanfiction, global identities, and imagination. Research in the Teaching of English, 43(4), 397-425.

Bogdan, R.C. \& Biklen, S.K. (2007). Qualitative Research for Education: An Introduction to Theories and Methods. New York: Pearson.

Bourdieu, P. (1977). Outline of a theory of practice. Cambridge: Cambridge University Press.

Bourdieu, P. (1982). Language and symbolic power. Cambridge, MA: Harvard University Press.

Brutt-Griffler, J. (2002). World English: A study of its development. Clevedon: Multilingual Matters.

Brutt-Griffler, J. (2007). Bilingualism and Elearning. In R. Andrews and C. Haythornthwaite (Eds.), The SAGE Handbook of E-learning Research (pp. 349-370). London: Sage.

Canagarajah, A.S. (1999). Resisting linguistic imperialism in English teaching. Oxford: Oxford University Press.

Cenoz, J. and Genesee, F. (2001). Trends in Bilingual Acquisition. Amsterdam: John Benjamins. 
Christenbury, L. (2008). A Consideration of the Ethics of Teaching English. English Journal, 97(6), 32-37.

Condry, I. (2006). Hip-Hop Japan: Rap and the Paths of Cultural Globalization. Stanford: Duke University Press.

Cope, B. and Kalantzis, M. (Eds.). (2000). Multiliteracies. New York and London: Routledge.

de Certeau, Michel. (1984). The practice of everyday life. Berkeley: University of California Press.

DiSciullo, A. \& Williams, E. (1987). On the Definition of a Word. Cambridge: MIT Press.

Doering, A., Beach, R., \& O'Brien, D. (2007). Infusing multimodal tools and digital literacies into an English education program. English Education, 40(1), 41-60.

Domingo, M. (2011a). Analysing layering in textual design: A multimodal approach for examining cultural, linguistic and social migration in digital video. International Journal of Social Research Methodology, 14(3), 219-230.

Domingo, M. (2011b). Migrating Literacies in Global and Digital Worlds: Exploring Linguistic Diversity, Cultural Knowledge and Social Identities of Urban Youth. Retrieved from ProQuest Dissertations and Theses. (Accession Order No. UMI 3478285).

Domingo, M. (2011c). "Migratory Practices in E-Learning and E-Communities Research.” In Andrews, R. \& Haythornwaite, C. (in press). E-Learning: Theory and Practice. London and New York: Sage.

Domingo, M. (2011d). Migrating Literacies. Retrieved September 20, 2011, from http://myrrhdomingo.com.

Dornfeld, B. (1998). Producing Public Television, Producing Public Culture. Princeton, NJ: Princeton University Press.

Dowdy, J.K. (2002). In L. Delpit (Ed.) The Skin that We Speak. New York: The New York Press.

Dyson, A. \& Genishi, C. (2005). On the Case: Approaches to Language and Literacy Research. New York: Teachers College Press.

Flower, L. (1994). The construction of negotiated meaning: A social cognitive theory of writing. Carbondale: Southern Illinois University Press. 
Foucault, M. (1980). The order of discourse. In R. Young (Ed.), Untying the text: A poststructuralist reader (pp.51-78). London: Routledge.

Freire, P. \& Macedo, D. (1987). Literacy: Reading the Word and the World. South Hadley: Bergin \& Garvey.

Gee, J.P. (1996). Social linguistics and literacies: Ideology in Discourses. London: Taylor \& Francis.

Gee, J.P. (2004). Situated language and learning: A critique of traditional schooling. New York: Routledge.

Gilyard, K. (1991). Voices of the self. Detroit: Wayne State University Press.

Goody, J. \& Watt, I. (1968). The consequences of literacy. In J. Goody (Ed.), Literacy in traditional societies (pp.27-68). Cambridge: Cambridge University Press.

Greene, M. (1995). Releasing the imagination: Essays on education, the arts, and social change. ( $1^{\text {st }}$ ed.). San Francisco: Jossey-Bass Publishers.

Greene, M. (2001). Variations on a blue guitar: The Lincoln Center Institute lectures on aesthetic education. New York: Teachers College Press.

Heath, S.B. (1986). Ways with Words. Cambridge: Cambridge University Press.

Heath, S.B. \& Street, B. (2008). Ethnography. Approaches to Language and Literacy Research. New York: Teachers College Press.

Heller, M. (1999). Linguistic Minorities and Modernity: A Sociolinguistic Ethnography. London: Longman.

Hull, G. (2003). Youth culture and digital media: New literacies for new times. Research in the Teaching of English, 38(2), 229-233.

Hull, G., \& Nelson, M.E. (2005). Locating the semiotic power of multimodality. Written Communication, 22(2), 224-62.

Hull, G., A., \& Nelson, M. A. (2009). Literacy, media, and morality: Making the case for an aesthetic turn. In M. Prinsloo \& M. Baynham (Eds.), The future of literacy studies (pp.199-227). New York: Palgrave MacMillan.

Hull, G. \& Schultz. (2002). Schools Out! Bridging Out of School Literacies with Classroom Practice. New York: Teachers College Press.

Hull, G., Zacher, J. \& Hibbert, L. (2009). Youth, Risk, and Equity in a Global World. Review of Research in Education, 33(1), 117-159. 
Jayakumar, U.M. (2008). Can Higher Education meet the Needs of an Increasingly Diverse and Global Society? Campus Diversity and Cross-Cultural Workforce Competencies. Harvard Educational Review, 4(78), 615-651.

Jewitt, C. (2008). Multimodality and Literacy in School Classrooms. Review of Research in Education, 32(1), 241-267.

Kachru, Y. (2006). World Englishes and Language Education. In Nero, S. (Ed.) (2006) Dialects, Englishes, Creoles, and Education. New York: Lawrence Erlbaum Associates.

Kellner, D. (2001). New Technologies/ New Literacies: Reconstructing Education for the New Millennium. International Journal of Technology and Design Education, 11(1), 6781.

Kirkland, D. (2008). Shaping the digital pen: Media literacy, youth culture, and Myspace. Youth Media Reporter, 2(4),188-200.

Kirkland, D. (2004). Rewriting School: Critical Writing Pedagogies for the Secondary English Classroom. Journal of Teaching of Writing 21(1\&2), 83-96.

Knobel, M., \& Lankshear, C. (2008). Remix: The Art and Craft of Endless Hybridization. Journal of Adolescent \& Adult Literacy, 52(1), 22-33.

Kress, G. (2010). Multimodality. A social semiotic approach to contemporary communication. London: Routledge.

Kress, G. (2010). A Grammar for Meaning-Making. In Locke, T. (2010) (Ed.). Beyond the Grammar Wars: A Resource for Teachers and Students Developing Language Knowledge in the English/Literacy Classroom, (pp.233-253). London: Routledge.

Kress, G. (2003). Literacy in the new media age. London: Routledge.

Kress, G. \& Van Leeuwen, T. (2001) Multimodal Discourse: the modes and media of contemporary communication. London: Hodder Arnold.

Lam, W.S.E. (2006). Culture and learning in the context of globalization: Research directions. Review of Research in Education, 30, 213-237.

Lam, W.S.E \& Rosario-Ramos, E. (2009). Multilingual literacies in transnational digitally mediated contexts: an exploratory study of immigrant teens in the United States. Language and Education, 23(2), 171-190.

Lankshear, C. \& Knobel, M. (2003). New literacies: Changing knowledge and classroom learning. Berkshire, UK: Open University Press. 
Leung, C., Harris, R., \& Rampton, B. (1997). The idealised native speaker, reified ethnicities, and classroom realities. TESOL Quarterly, 31(3), 543-560.

Levitt, P. \& Jaworsky, B.N. (2007). Transnational Migration Studies: past developments and future trends, Annual Review of Sociology, 30, 129-156.

Lewis, C. \& Fabos, B. (2005). Instant messaging, literacies, and social identities. Reading Research Quarterly, 40(4), 470-501.

McGinnis, T., Goodstein-Stolzenberg, A. \& Costa Saliani, E. (2007). 'indnpride': online spaces of transnational youth as sites of creative and sophisticated literacy and identity work. Linguistics and Education, 18(3), 283-304.

Mills, K.A. (2009). Multiliteracies: Interrogating competing discourses. Language and Education, 23(2), 103-116.

Moje, E.B., Overby, M., Tysvaer, N. \& Morris, K. (2008). The complex world of adolescent literacy: Myths, motivations, and mysteries. Harvard Educational Review, 78(1), 107-154.

Moll, L.C. (2009). Sixth Annual Brown Lecture in Education Research. Mobilizing Culture, Language, and Educational Practices: Fulfilling the Promises of Mendez and Brown. Educational Researcher, 39(6), 451-160.

Myers-Scotton, C. and Bolonyai, A. (2001). Calculating Speakers:

Codeswitching in a Rational Choice Model. Language in Society 30, 1-28.

Nero, S. (Ed.). (2006). Dialects, Englishes, Creoles, and Education. New York:

Lawrence Erlbaum Associates.

New London Group. (1996). A pedagogy of multiliteracies: Designing social futures. Harvard Educational Review, 66(1), 60-92.

Ochs, E. \& Schieffelin, B. (1986). Language and socialization: Three developmental stories and their implication. In Culture Theory: Essays on Mind, Self, and Emotion, New York: Cambridge University Press.Retrieved online May 4, 2009 from http://homepages.nyu.edu/ bs4/BambiWebsite_Assets/BBS\%20PDFs/3DStories4WEb.p df.

Olson, D. R. (1977). From utterance to text: The bias of language in speech and writing. Harvard Educational Review, 47, 257-81.

Ong, Walter J. (1982). Orality and literacy: The technologizing of the word. New York: Routledge. 
Pahl, K. (2007). Creativity in events and practices: A lens for understanding children's multimodal texts, Literacy, 41(2), 86-92.

Rampton, B. (1995). Crossing: Language and Ethnicity among Adolescents.

London: Longman.

Rubenstein-Avila, E. (2007). From the Dominican Republic to Drew High: What counts as literacy for Yanira Lara? Reading Research Quarterly, 42(4), 568-589.

Sankoff, D., and Poplack, P. (1981). A Formal Grammar for Code-Switching.

Papers in Linguistics 14(1-4), 3-45.

Scribner, S., \& Cole, M. (1981). The psychology of literacy. Cambridge, MA: Harvard University Press.

Sperling, M. \& DiPardo, A. (2008). English Education and Classroom Practice: New Directions for New Times. Review of Research in Education, 32(1), 62-108.

Stone, J. (2007). Popular websites in adolescents' out-of-school lives: Critical lessons on literacy. In M. Knobel \& C. Lankshear, (Eds.). A new literacies sampler (pp.49-66). New York: Peter Lang.

Street, B. (1983). Literacy in Theory and Practice. Cambridge, UK: Cambridge University Press.

Street, B. (1993). Cross-cultural approaches to literacy. Cambridge, UK: Cambridge University Press.

Suarez-Orozco, M. \& Qin-Hilliard, D. (Eds.) (2004). Globalization: Culture and Education in the Millenium. East Hampton, NY: University of California Press and Ross Institute.

Vygotsky, L.S. (1978). Mind in society: The development of higher psychological processes. Cambridge, MA: Harvard University Press.

West, K.C. (2008). Weblogs and literacy response: Socially situated identities and hybrid social languages in English class blogs. Journal of Adolescent and Adult Literacy, 51(7), 588-598.

Wheeler, S., Yeomans, P., \& Wheeler, D. (2008). The good, the bad and the wiki: Evaluating student generated content for collaborative learning. British Journal of Educational Technology, 39(6), 987-995.

Widdowson, H. (1994). The ownership of English. TESOL Quarterly, 28, 377-389. 
Williams, B. (2009). Shimmering Literacies. Popular Culture \& Reading and Writing Online. New York: Peter Lang Publishing, Inc.

Wolsey, T.D. \& Grisham, D.L. (2007). Adolescents and the new literacies: Writing engagement. Action in Teacher Education, 29(2), 29-38.

Yi, Y. (2009). Adolescent Literacy and Identity Construction among 1.5 Generation Students from a Transnational Perspective. Journal of Asia Pacific Communication, 19(1), 100-129. 